\title{
First record of the tadpole shrimp Triops cancriformis (Lamarck,1801) (Crustacea: Branchiopoda: Notostraca) in Portugal
}

\author{
Margarida Machado ${ }^{1}$, Luis Guilherme Sousa ${ }^{2}$, Luís Cancela da Fonseca ${ }^{3,4}$, Eliana Dinamene \\ Galioto $^{5}$ and Maria José Caramujo ${ }^{6, *}$
}

${ }^{1}$ CCMAR - Centre of Marine Sciences, Universidade do Algarve, Campus de Gambelas, 8005-139 Faro, Portugal.

${ }^{2}$ CIBIO-UE - Research Centre in Biodiversity and Genetic Resources, Research Group in Applied Ecology, Universidade de Évora, Mitra, 7002 Évora, Portugal.

${ }^{3}$ MARE - Marine and Environmental Sciences Centre, Laboratório Marítimo da Guia, Av. N. Sra. do Cabo 939, 750-374, Portugal.

${ }^{4}$ CTA - Centro de Ciências e Tecnologias da Água, Universidade do Algarve, Campus de Gambelas, 8005-139 Faro, Portugal.

${ }^{5}$ Escola de Ciências e Tecnologia, Universidade de Évora, Núcleo da Mitra, 7000 Évora, Portugal.

${ }^{6}$ CE3C Centre for Ecology, Evolution and Environmental Changes, Faculdade de Ciências, Universidade de Lisboa, Campo Grande, C2, $5^{\circ}$ Piso, 1749-016 Lisboa, Portugal.

* Corresponding author: mj.caramujo@fc.ul.pt

Received: $31 / 10 / 16$

Accepted: 10/02/17

\begin{abstract}
First record of the tadpole shrimp Triops cancriformis (Lamarck,1801) (Crustacea: Branchiopoda: Notostraca) in Portugal

Notostracan crustaceans identified as Triops cancriformis according to the presently accepted morphological criteria were recorded for the first time in Portugal in 2007. All previous records of Triops in Portugal belong to mauritanicus lineage species i.e. T. vicentinus or T. baeticus. A specimen purportedly belonging to T. cancriformis (Carvalho, 1944) has been re-identified by Machado in 2014 as T. baeticus after morphological examination. During 2007, hundreds of individuals of T. cancriformis were observed throughout the rice paddies on the northern margin of Sorraia River (Vale do Sorraia, Coruche). In the last 9 years, monthly checks during the rainy season have failed to record high population abundances and only a few specimens have been observed in the flooded tracks left by trucks and other heavy machinery on the elevated margins of the paddies. The low number of individuals observed in the latter years possibly results from changes of ecological conditions. Thus far, males of T. cancriformis have not been recorded, which may indicate that the observed population is either androdioecious or made of hermaphrodite or parthenogenetic populations. This situation contrasts with the other confirmed populations of this species in the Iberian Peninsula that are gonochoric. Parthenogenetic/hermaphrodite/androdioecious lineages, present in Northern and Central Europe, are considered to have derived from gonochoric Iberian populations in the Pleistocene which makes this finding all the more interesting in evolutionary terms. Has this population resulted from a recent recolonization from non-Iberian populations? Or has it derived directly from the assumed Iberian Pleistocene refuge? The potentially high dispersal abilities of Triops diapausing cysts and the possibility of hermaphrodite/parthenogenetic reproduction favour the 1st hypothesis of recolonization. Possible sources of individuals are (i) cysts attached to migratory birds arriving possibly from Southern France or Northern Italy and that are regularly seen feeding at these rice fields or ii) cysts unwittingly transported with the rice seeds used in the Vale do Sorraia. Both are in accordance with the assumption that nongonochoric reproductive mode confers a colonization advantage over gonochoric populations, which lack evidence of fast long distance dispersal ability. Future multilocus phylogenetic analysis is expected to clarify the origin of T. cancriformis found in the Sorraia's rice fields.
\end{abstract}

Key words: Large branchiopods, rice fields, temporary ponds, androdioecy, hermaphrodites, gonochoric. 


\begin{abstract}
RESUMO
Primeiro registo do grande branquiópode Triops cancriformis (Lamarck, 1801) (Crustacea: Branchiopoda: Notostraca) em Portugal

Crustáceos identificados como Triops cancriformis (Crustacea, Notostraca) de acordo com os critérios morfológicos actualmente adoptados, foram registados pela primeira vez em Portugal em 2007. Todos os Triops anteriormente encontrados em Portugal pertencem a espécies da linhagem mauritanicus, ou seja T. vicentinus ou T. baeticus. A identificação de uma amostra existente no Museu de Coimbra e referida como T. cancriformis (Carvalho, 1944) foi emendada para T. baeticus em 2014, por M. Machado, após análise morfológica. Em 2007, foram observadas centenas de indivíduos de T. cancriformis nos arrozais da margem norte do rio Sorraia (Vale do Sorraia, Coruche). Prospecções mensais durante a época das chuvas nos últimos 9 anos, não voltaram a evidenciar abundâncias tão elevadas, tendo-se apenas observado alguns indivíduos em sulcos inundados deixados por camiões e máquinas agrícolas nas margens elevadas de alguns canteiros de arroz. Este reduzido número de indivíduos observado nos últimos anos resulta, possivelmente, de alterações nas condições ecológicas. Não se encontraram, até agora, indivíduos machos de T. cancriformis, o que pode indicar que a população observada é androdióica, ou hermafrodita, ou partenogenética. Esta situação contrasta com as outras populações confirmadas desta espécie na Península Ibérica, que são gonocóricas. Linhagens partenogenéticas/hermafroditas/androdióicas, presentes no Norte e Centro da Europa, são consideradas como tendo derivado de populações gonocóricas ibéricas no Pleistoceno, o que torna esta descoberta ainda mais interessante em termos evolutivos. Terá essa população resultado de uma recolonização recente com origem em populações não-ibéricas? Ou derivará directamente do assumido refúgio pleistocénico Ibérico? A capacidade potencialmente elevada de dispersão de cistos de Triops em diapausa e a possibilidade de reprodução hermafrodita/partenogenética favorecem a hipótese de recolonização recente a partir de (i) cistos transportados por aves migratórias possivelmente provenientes do sul de França ou do norte de Itália e que são regularmente vistas a alimentarem-se nestes campos de arroz ou de (ii) cistos inadvertidamente introduzidos via sementes de arroz utilizadas no Vale do Sorraia. Ambas as possibilidades estão em conformidade com o pressuposto de que o modo reprodutivo não gonocórico confere vantagens de dispersão e colonização relativamente a populações gonocóricas, que não evidenciam capacidade de dispersão rápida a longa distância. Espera-se que uma futura análise filogenética multilocus possa vir a esclarecer a origem de T. cancriformis nos arrozais do Sorraia.
\end{abstract}

Palavras-chave: Grandes branquiópodes, arrozais, charcos temporários, androdioicia, hermafroditas, gonocóricos.

\section{INTRODUCTION}

Species of the tadpole shrimp Triops (Schrank, 1803) have a scattered distribution in all continents except Antarctica (Vanschoenwinkel et al., 2012; Korn et al., 2013). Triops morphology in the fossil record appears to be indistinguishable from that of modern forms by the Upper Triassic (Trusheim, 1938) and morphological similarities may extend to the Permian (Guthörl, 1934; Gand et al., 1997; Korn et al,. 2013). The conservative form exhibited by modern Triops is typically accompanied by high morphological individual variability, and low number of known morphological characters of taxonomic significance. This rendered correct species identification nearly impossible until the revision by Longhurst in 1955 who retained only taxonomic entities that could be distinguished (i.e. diagnosable morphospecies). Molecular phylogenetic studies in the last decades, allied with morphological re-investigation, have clarified various instances of cryptic diversification and led to taxonomic revisions worldwide (Korn et al., 2013; Mathers et al., 2013; Korn \& Hundsdoerfer, 2016; Meusel \& Schwentner, 2016). In the Mediterranean region, at least 2 taxa formerly attributed to Triops granarius (Lucas, 1864), and at least 7 taxa formerly attributed to Triops cancriformis sensu lato are known to occur (Korn et al., 2006; 2010; Korn \& Hundsdoerfer, 2006; 2016). Korn et al. (2006), using mitochondrial $16 \mathrm{~S}$ and $12 \mathrm{~S}$ rDNA sequences, investigated the phylogenetic relationships among the three subspecies of Triops cancriformis recognized at the time and identified two distinct lineages.

One lineage encompasses T. c. cancriformis populations from central and northern Europe and samples from northern Spain (Espolla temporary pond, Girona, $42^{\circ} 09^{\prime} 02^{\prime \prime} \mathrm{N}, 02^{\circ} 45^{\prime} 60^{\prime \prime} \mathrm{E}$ ) 
that had been hitherto classified as T. cancriformis of the simplex form (Alonso, 1985; 1996). The common lineage of the population of Espolla and the other European populations has been corroborated in a subsequent study by Zierold et al. (2007). These authors named the individuals from Espolla as T. $c$. simplex referring to the previous identification by Alonso (1985; 1996) and Boix et al. (2002), and observed that this population and other population from "El Puig" (inacurate coordinates $39^{\circ} 34^{\prime} 24^{\prime \prime} \mathrm{N}, 00^{\circ} 16^{\prime} 43^{\prime \prime} \mathrm{E}$, possibly $39^{\circ} 34^{\prime} 24^{\prime \prime} \mathrm{N}, 00^{\circ} 16^{\prime} 43^{\prime \prime} \mathrm{W}$ near El Puig de Santa Maria, Comunitat Valenciana, Spain) shared haplotype $\mathrm{H} 1$ with five $T$. $c$. cancriformis individuals from four different populations in Germany. The authors remarked that "the two morphologically described subspecies T. c. cancriformis and T. c. simplex, which show different reproductive modes, are not represented by distinct monophyletic lineages". As noted by Korn et al. (2006) after morphological re-examination of specimens with comparison to molecular data, the former T. c. simplex cannot be reliably separated from T. c. cancriformis, using the morphological characters that had hitherto been used to distinguish among subspecies of $T$. cancriformis.

The second lineage of Triops cancriformis sensu lato comprises all populations of former T. c. mauritanicus and the northern African populations of T. c. simplex (Ghigi, 1921) (Korn et al., 2006). This lineage contains the predominant species in the Iberian Peninsula, T. mauritanicus, which was originally established by Ghigi (1921), later considered a subspecies of T. cancriformis by Longhurst (1955), and re-instated to full species status by Korn et al. in 2006. The clarification of the gross phylogenetic relationships within the group resulted in the inclusion of the northern African populations of the former T. cancriformis simplex as a subspecies of T. mauritanicus. Later records have shown that T. m. simplex is also present in Spain. In 2007, a population of Triops from Ares del Maestre $\left(40^{\circ} 25^{\prime} 19^{\prime \prime} \mathrm{N}, 00^{\circ} 04^{\prime} 13^{\prime \prime} \mathrm{W}\right.$, Comunitat Valenciana, Spain) was identified by Zierold et al. (2007) under the invalid name $T$. cancriformis mauritanicus, based on nucleotide sequencing in two mtDNA genes. Korn et al. (2010) comparing the corresponding COI sequence retrieved from GenBank with those obtained from a representative subset of $T$. mauritanicus samples re-assigned that population to T. $m$. simplex. Interestingly, Korn et al. (2010) noted that T. $c$. cancriformis (first lineage) and T. m. simplex (second lineage) co-occur on a regional scale in northern Spain, highlighting the need to perform a phylogeographic study allied to a sound morphological re-investigation of northern Spanish populations.

Further analysis by Korn et al. in 2010 of main lineages in Triops mauritanicus Ghigi, 1921 in the south-western Iberian Peninsula indicated the presence of four more clades. As their data suggested that these clades represent distinct species, Korn et al. (2010) described the Iberian lineages as T. baeticus Korn, T. emeritensis Korn \& Pérez-Bote, T. gadensis Korn \& García-deLomas and T. vicentinus Korn, Machado, Cristo \& Cancela da Fonseca, and reinstated T. simplex Ghigi, 1921 to full species status. T. mauritanicus Ghigi, 1921 is represented by populations in northern Africa alone (Korn et al., 2006; 2010). Six species are therefore recognized as present in the Iberian Peninsula: five species from the mauritanicus lineage plus one species from the cancriformis lineage.

Contrasting with their conserved morphology, Triops exhibit a wide range of reproductive modes. The ancestral reproductive mode is apparently gonochorism (Pannell, 2002; Zierold et al., 2007; Mathers et al., 2013) with equal sex ratio populations and cross-fertilization necessary to produce viable eggs (Korn et al., 2006). Certain populations lack males and individuals possess ovotestis and have the ability to breed in isolation (Sassaman, 1991; Zaffagnini \& Trentini, 1980). In other populations, males and hermaphrodites co-occur in varying frequency, and there are varying levels of self-fertilisation and outcrossing; a system named androdioecy (Pannell, 2002). The inbreeding depression, reduction in effective recombination rates and reduction in effective population size resulting from the deleterious effects of self-fertilisation (Glemin et al., 2006) may be off-set by the benefits of coloniza- 
tion advantage and reproductive assurance in a metapopulation (Baker, 1955; see Mathers et al., 2013). On the one hand, the often unpredictable environment of ephemeral ponds where branchiopod populations have strong inter-annual density fluctuations could drive the evolution of androdioecy by ascribing higher fitness to self-fertilising hermaphrodites relative to females (Weeks et al., 2006). On the other hand, considering that Triops produce long-lived dormant cysts that survive during adverse periods and also provide the dispersal stage (Fryer, 1988; Longhurst, 1955), evolution towards self-fertile hermaphroditism could both increase the success of populations and its dispersal probabilities.

Triops Iberian populations are considered gonochoric while Central and Northern European populations where males are absent or present in a low proportion, are considered hermaphrodite and/or androdioecious (Zierold et al., 2007; 2009; Korn et al., 2006; Mathers et al., 2013). Some controversy remains regarding the reproductive strategy in some Central Euro- pean and Italian populations with suggestions of parthenogenesis or a mixture of gonochoric and hermaphroditic reproduction in a German population (Engelmann et al., 1997), and meiotic parthenogenesis and selfing hermaphroditism in some Italian populations (Trentini \& Scanabissi, 1979; Zaffagnini \& Trentini, 1980). Studies in the last decade have shown that modern parthenogenetic/hermaphrodite/androdioecious lineages of Triops cancriformis present in Northern and Central Europe are considered to have derived from those located in glacial Pleistocene refuges after the last glacial maximum; i.e. possibly in southern Iberia, Sardinia, Sicily and areas of mainland Italy and Greece (Korn et al., 2006; Zierold et al., 2007).

Here we report the first record of the tadpole shrimp Triops cancriformis (Lamarck, 1801) in rice fields of southern Portugal. Contrasting to the other Iberian populations of Triops which are purportedly all gonochoric, males were absent from the sampled populations from the rice fields on the north margin of Sorraia River.

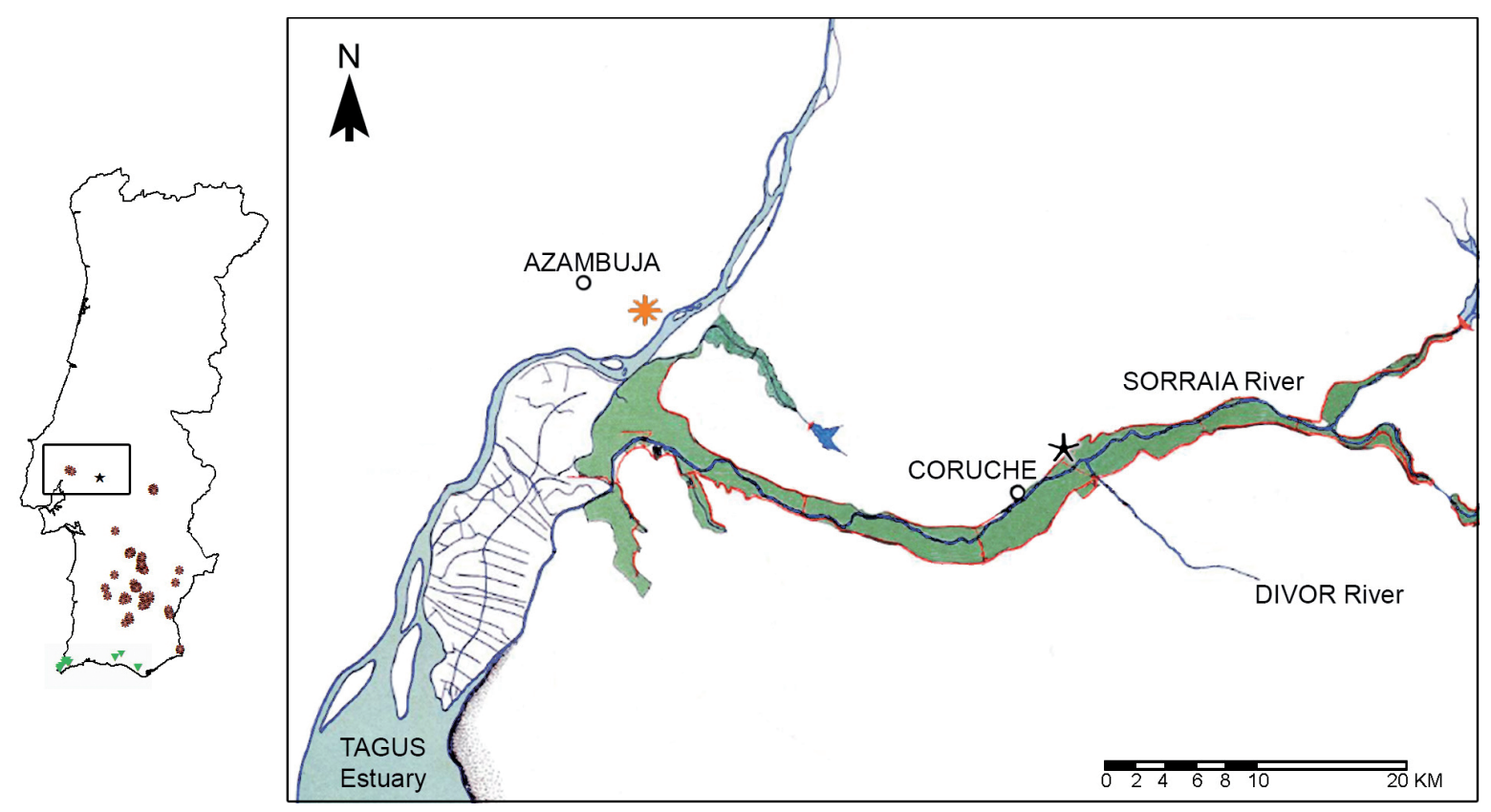

Figure 1. Geographical records for T. baeticus (asteriscs), T. cancriformis (black star) and T. vicentinus (triangles) in Portugal and in Vale do Sorraia. Distribution of T. baeticus and T. vicentinus according to M. Machado, L. Cancela da Fonseca and M. Cristo (unpublished data). Registos geográficos de T. baeticus (asteriscos), T. cancriformis (estrela negra) e T. vicentinus (triângulos) em Portugal e no Vale do Sorraia. Distribuição de T. baeticus e T. vicentinus segundo M. Machado, L. Cancela da Fonseca e M. Cristo (dados não publicados). 
The absence of males suggests a prevailing hermaphrodite or androdioecious sexual system in the populations and we present and discuss two hypotheses for this possible absence of gonochorism. The $1^{\text {st }}$ hypothesis proposes colonization by a single or few selfing hermaphrodites or parthenogenetic individuals, and the $2^{\text {nd }}$ hypothesis considers that Triops cancriformis from Vale do Sorraia derived directly from gonochoric populations from the Iberian Pleistocene refuge.

\section{MATERIALS AND METHODS}

\section{Study site}

The rice fields surveyed in this study are located in the Tagus river basin $\left(38^{\circ} 58^{\prime} 42^{\prime \prime} \mathrm{N}\right.$, $\left.8^{\circ} 29^{\prime} 0^{\prime \prime} \mathrm{W}\right)$, Portugal, in the alluvial plains of the Sorraia river (Fig. 1). These alluvial plains, dominated by rice fields and irrigation crops, are bordered by open oak forest. The paddies are filled with rainwater from October to March when soil is prepared for the cultivation of rice (Oriza sativa). During the period of rice cultivation, from April/May to September/October, the water level in the paddies is controlled through the irrigation system of locks, boxes and channels (Associação de Regantes e Beneficiários do Vale do Sorraia, 2012). The exotic plant Azolla filiculoides, the exotic red swamp crayfish Procambarus clarkii and mosquitofish Gambusia holbrooki were present in the majority of the inspected paddies. Avian fauna, which are recognized as long distance dispersal vectors (Viana et al., 2016) and use rice fields as feeding areas (Elphick, 2010 and references therein), were assessed by walking transepts from the outer edge of the fields in direction of the river, with the aid of binoculars. Field collected information was complemented with literature records for the area and information obtained from researchers involved in ringing-recovery programmes for aquatic birds (V. Encarnação and E.D. Galioto). Supplementary information on migratory birds was collected from BirdLife International (2015) and literature. The avian species feeding in the area are: flamingos Phoenicopterus roseus (partially migrant), black-winged stilts Himantopus himantopus (migrant) spoonbills Platalea leucorodia (migrant), great white egrets Egretta alba (syn. Ardea alba, migrant), cattle egrets Bubulcus ibis (partially migrant), little egrets Egretta garzetta (migrant to nomadic), night heron $\mathrm{Nyc}$ ticorax nycticorax, (migrant), grey heron Ardea cinerea (partially migrant or sedentary), purple heron Ardea purpurea (migrant), white stork Ciconia ciconia (migrant or sedentary), the northern lapwing Vanellus vanellus (migrant) and mallard Anas platyrhynchos (sedentary or nomadic).

\section{Sampling and Identification}

The rice fields were inspected for the presence of large branchiopods every month from October to May (2007-2016), or during the period when they were filled with rainwater. Flooded expanses within the rice paddies were prospected with dip-nets $(0.250 \mathrm{~mm}$ pore mesh size $)$ or hand held sieves ( $1 \mathrm{~mm}$ pore mesh size). Large branchiopods were collected in May 2012, in February and April 2014, and March, 2016. After collection, specimens were sorted, anaesthetized with carbonated water and preserved in $70 \%$ ethanol for laboratory identification. The morphology of adult Triops was studied according to Korn et al. (2006) and Longhurst (1955) and specimens were identified following the criteria adopted by Korn et al. (2006). The recorded biological data were: (i) telson length ratio calculated as the ratio of furcal spine length to the distance between furcal spine tip and the anterior-lateral edge of the telson (see figure 1 in Korn et al., 2006); carapace length (measured at carina level); (ii) number and type of carina spines; (iii) number of apodous abdominal segments, and (iv) sex. Morphological females present a brood pouch at each side of the body that results from a modification of the endopodite and the exopodite of each branch of the $11^{\text {th }}$ pair of thoracopods. 


\section{RESULTS}

Morphological observation of the sampled 40 specimens revealed that 28 were juveniles and 12 were adults (Table 1). It was possible to recognize the presence of a pair of brood pouches in all individuals, which proved them to be morphological females. Males have not been recorded, which may indicate that the observed population is either androdioecious or made of hermaphrodite or parthenogenetic individuals.
The 12 adults exhibited small furcal spines as shown by a lower telson length ratio (0.21-0.29; mean value: 0.25$)$ than that of the mauritanicus lineage ( $\geq 0.38)$ in the Iberian Peninsula (Table 1), with the exception of $T$. simplex (see Introduction). This morphological characteristic together with the sex ratio of the sample allowed us to unambiguously identify the specimens as Triops cancriformis. The specimens were compared with $T$. baeticus belonging to the mauritanicus lineage of Triops, and previously collected in

Table 1. Morphological characteristics of Triops (Vale do Sorraia) and diagnostic characteristics of T. cancriformis and of the endemic Iberian species of T. mauritanicus lineage as defined by Korn et al. (2006) and Longhurst (1955). Carina spines are counted from the distal spine; carapace length is measured at carina level in both adults (Ad) and juveniles (Juv); telson length ratio characterizes the length of furcal spines (see Methods). All observed specimens, including juveniles, were females (F); sex was determined based on morphology. States of the most important character for species identification are presented in bold. Características morfológicas de Triops (Vale do Sorraia) e características diagnosticantes de T. cancriformis e das espécies Ibéricas endémicas da linhagem T. mauritanicus, tal como definidas por Korn et al. (2006) e Longhurst (1955). Os espinhos da carena são contados a partir do espinho distal; o comprimento da carapaça é medido ao nível da carena em adultos (Ad) e juvenis (Juv); o rácio do comprimento do telson caracteriza o comprimento dos espinhos da furca (ver Métodos). Todos os espécimens observados, incluíndo os juvenis, eram fêmeas $(F)$; o sexo foi determinado com base na morfologia. Os estados do caracter mais relevante para a identificação das espécies estão em negrito.

Characteristics exhibited by Sorraia individuals (Ind.)

\begin{tabular}{|c|c|c|c|c|c|c|c|c|c|c|}
\hline \multirow{2}{*}{$\begin{array}{c}\text { Ind. } \\
(n=40)\end{array}$} & \multirow[t]{2}{*}{ Sex } & \multicolumn{3}{|c|}{ Carina spines } & \multicolumn{2}{|c|}{ Telson length ratio } & \multicolumn{3}{|c|}{ Number of apodous segments in females } & \multirow{2}{*}{$\begin{array}{c}\text { Carapace } \\
\text { Length }(\mathrm{mm})\end{array}$} \\
\hline & & Type & N.er & Median & Range & $\begin{array}{l}\text { Mean } \\
\pm \mathrm{SD}\end{array}$ & Range & $\begin{array}{l}\text { Mean } \\
\pm \mathrm{SD}\end{array}$ & $\begin{array}{c}95 \% \text { confidence } \\
\text { intervals }\end{array}$ & \\
\hline 12 Adult & & minute & $0-13$ & 4 & $0.21-0.29$ & $\mathbf{0 . 2 5} \pm 0.023$ & $4.5-6.0$ & $96 \pm 0.547$ & $4.653-5.272$ & $\begin{array}{c}16.6-38(12 \mathrm{Ad}) \\
4-9(28 \mathrm{Juv})\end{array}$ \\
\hline
\end{tabular}

\begin{tabular}{|c|c|c|c|c|c|c|}
\hline \multicolumn{7}{|c|}{ Triops cancriformis } \\
\hline $\begin{array}{l}\text { Korn et al., } \\
2006\end{array}$ & Mostly small & $\begin{array}{c}0-30 \\
\text { often } 0-4\end{array}$ & $\begin{array}{c}\text { Haplotype group means: } \\
\mathbf{0 . 2 1 - 0 . 2 7}\end{array}$ & - & - & $\begin{array}{l}4.0-5.6(a) \\
4.0-6.8(b)\end{array}$ \\
\hline $\begin{array}{l}\text { Longhurst, } \\
1955 \mathrm{a}\end{array}$ & Small & $\begin{array}{c}0-10 \\
\text { often } 2-3\end{array}$ & $\begin{array}{l}\text { size of furcal } \\
\text { spines: small }\end{array}$ & $4-6$ & - & - \\
\hline
\end{tabular}

Triops mauritanicus

Endemic

Iberian Gradient sized,

Species largest next to

Korn et al., distal spine

Numerous, Haplotype group

often $>50$ means: $\geq \mathbf{0 . 3 8 - 0 . 4 4}$ (c)

$-\quad \quad-\quad 4.7-6.2(\mathrm{c})$

2006, 2010

\begin{tabular}{lllll}
\hline $\begin{array}{l}\text { Longhurst, } \\
\text { Strong, }\end{array}$ & & & \\
1955 & $\begin{array}{c}\text { largest sub-equal } \\
\text { to distal spine }\end{array}$ & - & Strong furcal Spines & $5-7$ \\
& & &
\end{tabular}

(a, b, c) Values inferred from Figure 5-A and 5-B in Korn et al. (2006) considering (a) only nongonochoric populations, (b) including the gonochoric population from Espolla, and (c) Iberian populations of the mauritanicus complex. 
Azambuja, approximately $40 \mathrm{~km}$ northwest of the rice fields sampled in this study (Fig. 2). It is also interesting to note the minute carina spines

\section{Triops baeticus Azambuja}
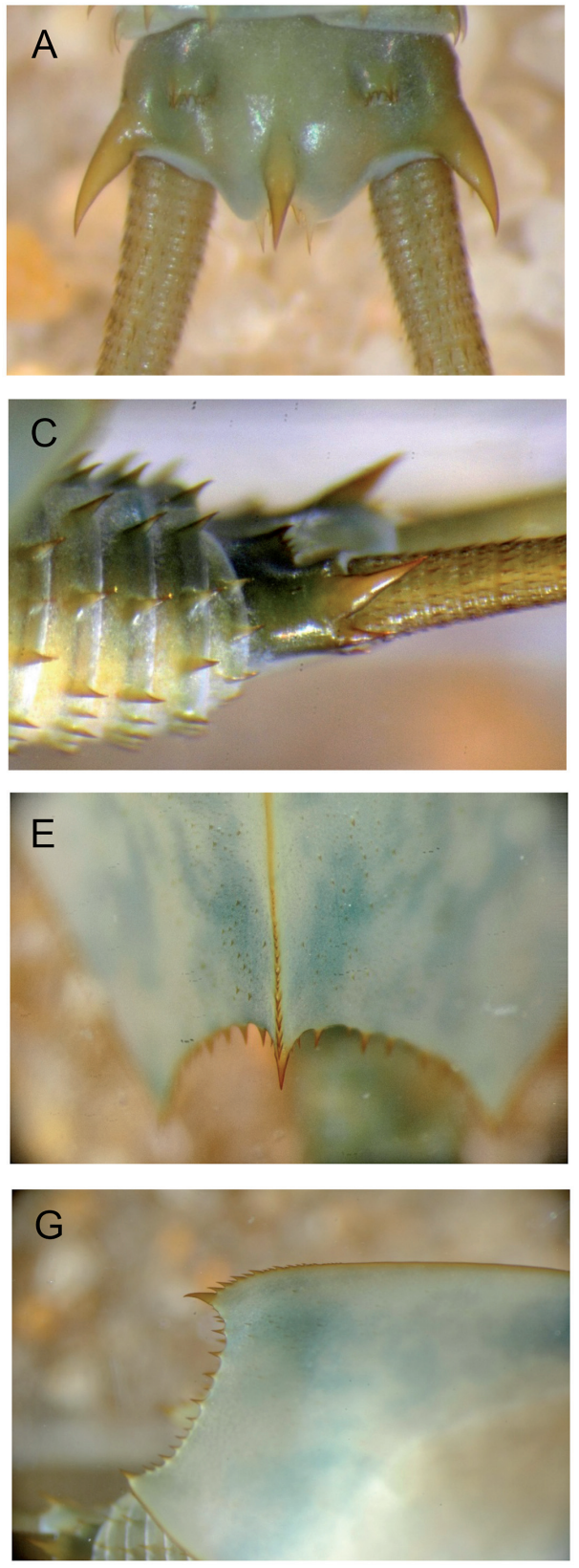

anterior to the distal spine observed in the specimens identified as $T$. cancriformis relative to the larger spines observed in T. baeticus.

\section{Triops cancriformis Sorraia}
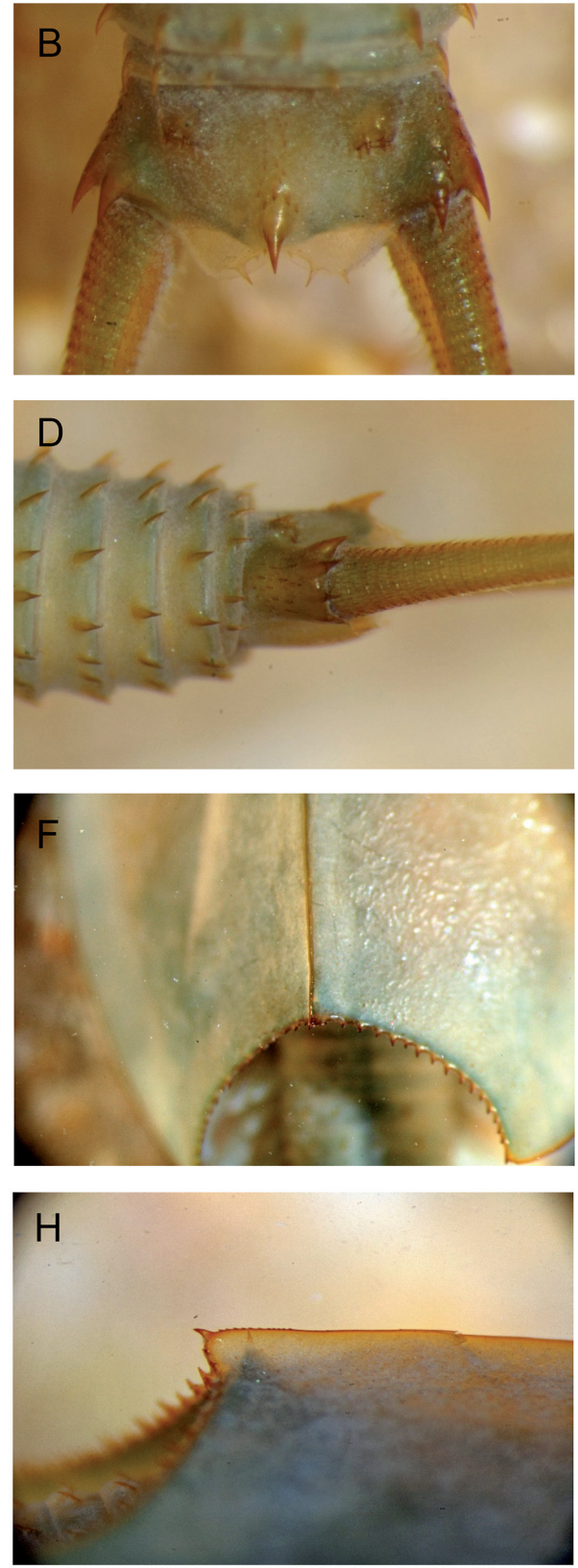

Figure 2. Morphological characteristics of T. cancriformis from Vale do Sorraia compared with those of T. baeticus from Azambuja: Posterior part of the body, dorsal view (A, B); posterior part of the body, lateral view (C, D); posterior part of carapace carina, dorsal view (E, F); posterior part of carapace carina, lateral view $(\mathrm{G}, \mathrm{H})$. Comparação das características morfológicas de $\mathrm{T}$. cancriformis do Vale do Sorraia com as de T. baeticus da Azambuja: parte posterior do corpo, visão dorsal (A, B); parte posterior do corpo, visão lateral $(C, D)$; parte posterior da carena da carapaça, visão dorsal $(E, F)$; parte posterior da carena da carapaça, visão lateral $(G, H)$. 


\section{DISCUSSION}

The Triops population inhabiting the rice fields of Vale do Sorraia could be unambiguously ascribed to the species Triops cancriformis both by morphological analysis and by the observed sex ratio that suggests a nongonochoric reproductive type. The absence of males in a sample of 40 individuals strongly suggests that these either reproduce by selfing hermaphroditism or automictic parthenogenesis, or by androdioecy (Zierold et al., 2009; Mathers et al., 2013). These are the most widespread reproductive modes in $T$. cancriformis, which has only one known gonochoric population i.e. that of the Espolla temporary pond in the eastern Iberian Peninsula (Korn et al., 2006; Boix et al., 2002). Scanabissi et al. (2005) reported the occurrence of a population with equal sex ratio in Corbières, southern France referenced to Nourisson \& Thiery (1988). This is probably a mistake because Nourisson \& Thiery do not make such claim in their article, and as noted by Korn et al. (2006), "Thiéry (1988) only reported one population of Triops (T. c. cancriformis) in that region (Opul temporary pond), from which Knoepffler (1978) reported the complete absence of males in a sample of 300 specimens". Zierold et al. (2007) noted that the population from Espolla (and other from El Puig, Spain) shared haplotype H1 with five T. c. cancriformis individuals from four different populations in Germany, and concluded that the populations that "show different reproductive modes, are not represented by distinct monophyletic lineages".

The Sorraia population also presents morphological similarity to T. simplex. In fact, morphological characters distinguishing T. cancriformis from T. simplex are not known (Korn et al., 2006) and in the past, populations of T. cancriformis have been attributed to the former $T$. $c$. simplex, considered a sub-species of $T$. cancriformis at the time (Alonso, 1985; 1996; Boix et al., 2002; Zierold et al., 2007). Only recently the classification based on genetic sequences has been established for these species by Korn $e t$ al. $(2006 ; 2010)$. T. simplex is present in Eastern Spain with a population in Ares del Maestre
(Comunitat Valenciana), a location well within the distribution area of $T$. cancriformis in the Iberian Peninsula, and that may explain why some authors disagree on the taxonomic identity of Triops populations in that region (see Korn et al., 2006; 2010 and Zierold et al., 2007). Nevertheless, all reported populations of $T$. simplex are gonochoric (Longhurst, 1955; Thièry, 1996; Korn et al., 2006; Hassan, 2015) which enables the assignment of the Sorraia population to the species Triops cancriformis (where non-gonochoric populations are known) without performing a genetic study.

The presence of this hermaphroditic/parthenogenic or androdioecious population of T. cancriformis in the Iberian Peninsula contrasts with the gonochoric nature of that from Espolla and makes its finding all the more interesting in evolutionary terms. The gonochoric reproductive mode is considered to be the ancestral condition (Zierold et al., 2007 and references therein). Korn et al. (2006) hypothesized that a nongonochoric lineage has originated from a gonochoric ancestor located in Spain that would form parthenogenetic/hermaphroditic and androdioecious populations. This nongonochoric lineage would further diverge while spreading eastwards during postglacial periods in the Pleistocene, namely to mainland Italy and Israel (see Korn et al., 2006 and references therein). These two areas should have not lost Triops populations during the Ice Ages, and like the Iberian Peninsula could have offered a Pleistocene refuge to ancient lineages. The parthenogenetic/hermaphrodite/androdioecious lineages present nowadays in Northern and Central Europe are considered to have derived from those glacial Pleistocene refuges after the last Ice Age (Korn et al., 2006; Zierold et al., 2007).

Consequently, the question arises concerning the origin of the population recently found in Sorraia rice fields. Has it derived directly from the assumed Iberian Pleistocene refuge? Or has it resulted from a recent colonization from non-Iberian populations? To discuss the first hypothesis, we have to consider that the only confirmed T. cancriformis population in Iberia (from Espolla, Spain) is gonochoric. Recent- 
ly, other population of Triops was recorded by Sahuquillo (2012) at Rebalsador $\left(39^{\circ} 49^{\prime} 31^{\prime \prime} \mathrm{N}\right.$, $00^{\circ} 39^{\prime} 51^{\prime \prime} \mathrm{W}$, Comunitat Valenciana, eastern Spain), which is located $387 \mathrm{~km} \mathrm{SE}$ from Espolla and $83 \mathrm{~km}$ SE to Ares del Maestre. This population is probably gonochoric since 7 males were observed in a sample of 12 specimens. The morphology of the individuals was consistent with both T. cancriformis and T. simplex (see Table 4.2 in Sahuquillo, 2012) and the unambiguous identification of the Rebalsador population requires a genetic study. If this population belongs indeed to T. cancriformis, it should have derived directly from the gonochoric ancestor located in Spain, as hypothesized by Korn et al. (2006). Considering that the population from El Puig (Comunitat Valenciana, Eastern Spain, which is ca. $58 \mathrm{Km}$ from Rebalsador) has the same haplotype than that of Espolla (Zierold et al. 2007), it would be relevant to genetically analyse the three populations plus the population from Sorraia to clarify how they are related. Unhappily the reproductive mode of the El Puig population is not mentioned by Zierold et al. (2007). If this population and that from Sorraia are both nongonochoric and share the same haplotype with the population from Espolla, they may both derive from the primitive nongonochoric lineage, as hypothesized by Korn et al. (2006) (see above). If only the population from Sorraia is nongonochoric and share the haplotype with the population from Espolla, then the population from Sorraia may be the only known population derived from the primitive nongonochoric populations from the Iberian Pleistocene refuge. As there is no evidence of long-distance dispersal for gonochoric populations (Korn et al., 2006), the probability that the Portuguese population has derived directly from gonochoric populations from the Iberian Pleistocene refuge is quite low.

The potentially high dispersal abilities of Triops spp. diapausing cysts and the reproductive mode inferred for the Portuguese population seems to favour the $2^{\text {st }}$ hypothesis of recent colonization from non-Iberian populations, as a single selfing hermaphrodite or parthenogenetic individual can theoretically originate a new population while a minimum of two cysts originating individuals of different sex would be required to start a population (Korn et al., 2006; Zierold et al., 2007). The hermaphrodite or parthenogenetic population would also have a greater reproductive potential (i.e. all individuals lay eggs) relative to gonochoric populations composed of roughly 50\% males (Zaffagnini \& Trentini, 1980). The founding cyst(s) could result from long-distance passive dispersal through external transport by migratory birds. Rice fields are highly frequented by migrant waterbirds, functioning normally as feeding areas (Elphick, 2010 and references therein). In the Sorraia rice pads several bird species could be observed including flamingos, black-winged stilts, spoonbills (V. Encarnação, pers. obs.), great white egrets and northern lapwings. Except for the spoonbill, these species use or visit the rice fields from Camargue (France, Tourenq et al., 2001; 2003). National ringing-recovery programs for aquatic birds have shown that E. alba comes from the central Europe (mainly Hungary) while the other species arrive from Camargue and/or from the mainland of Italy (V. Encarnação, pers. com.). At Camargue, the occurrence of maleless populations of T. cancriformis is known from 1951 (Zaffagnini \& Trentini, 1980; Pont \& Vaquer, 1986). In mainland of Italy, where no gonochoric populations of this species have been found (Korn et al., 2006; Mantovani et al., 2008), T. cancriformis is known to occur in a considerable number of rice fields (Zaffagnini \& Trentini, 1980; Golfieri \& Bonato, 2014). For some of these populations, males have been reported as absent, while for the major part of populations the sex system is unknown (Golfieri \& Bonato, 2014). Gill et al. (2005) has confirmed the ability of an aquatic bird species to perform nonstop flights as long as $11000 \mathrm{~km}$. Flamingos, black-winged stilts and spoonbills, coming from the South of France or from the Italian rice fields to those at Vale do Sorraia, are able to cover the distance through one nonstop flight (V. Encarnação, pers. com.). Hence they can act as vectors for the colonization of those Portuguese rice fields by a nongonochoric population of T. cancriformis from Central Europe, when transporting cysts attached to feathers or to their legs (Viana et al., 2016). 
The other possible vector for this colonization is the rice seed that is used for production in the Vale do Sorraia. Seeds are routinely imported from Italy, which is the main rice producer in Europe, by rice growers associations and companies e.g. Lusosem that imports seeds from Almo Company (Novara, Italia) (Lusosem, 2010; A. S. Almeida, pers. com.). Some dry Triops cysts can eventually be unwittingly transported with those seeds as it is known to occur with other crustaceans inhabiting temporary freshwater habitats (McKenzie \& Moroni, 1986) and with the main introduced weeds in rice fields (Vasconcelos et al., 1999).

Other possibility for the origin of the Portuguese population would be a modification of the second hypothesis i.e. it derives from the $T$. cancriformis populations inhabiting rice fields of northern and eastern Spain, which had themselves originated from Central and Northern European populations. Indeed, Triops has been recorded in Spanish rice fields since the early $20^{\text {th }}$ century (Arévalo, 1915; Font de Mora, 1923; Bolivar, 1926; all cited in Boix, 2002). Later, this taxon was reported from several other rice fields from northeastern to eastern Spain (Forés et al., 1986; Boix, 2002). Some of those populations should be nongonochoric as stated by Longhurst (1955). Populations from eastern Spain (Comunitat Valenciana) previously reported as $T$. cancriformis simplex by Alonso (1985) may belong to $T$. cancriformis as suggested by the results of Zierold et al. (2007). These authors identified 2 haplotypes of $T$. cancriformis from Ullal de Baldovi, which is completely surrounded by Albufera de València rice fields. Those haplotypes are closer to some haplotypes from Central and northern Europe then to the supposedly primitive haplotype from Espolla. This strongly suggests that the $T$. cancriformis population from Albufera de València rice fields has originated from Central and northern Europe populations through long distance dispersal recent events. Cysts from the Spanish populations inhabiting rice fields could have been transported by aquatic birds and then disperse and colonize the Sorraia rice fields. Internal transport by birds is also a possibility. The resistant stages of some invertebrate are viable after $26 \mathrm{~h}$ retention in the gut of mallards (Green \& Figuerola, 2005). Considering a distance of approximately $750 \mathrm{~km}$ between Albufera de València and Sorraia rice fields where mallards have been observed (Albufera de València, 2009) and that mallards can fly up to $110 \mathrm{~km} / \mathrm{h}$ (Wikipedia, 2016), these birds may disperse Triops resistant eggs.

The origin of the population of $T$. cancriformis inhabiting the rice fields of Sorraia can only be clarified by multilocus phylogenetic analysis of Triops specimens from rice field populations from Camargue, Italy and the Iberian Peninsula. An exhaustive genetic study of the Triops populations known hitherto in the northern and eastern Spain and previously identified as $T$. c. simplex, integrating information on the sexual systems of the populations, is imperative to fully understand the distribution patterns of both T. cancriformis and of the several other Triops species that are known to coexist in the Iberian Peninsula.

\section{ACKNOWLEDGMENTS}

The work was partially funded by FCT-Fundação para a Ciência e a Tecnologia, through the projects UID/BIA/00329/2013, UID/MAR/04292/ 2013 and UID/Multi/04326/2013. We wish to acknowledge the valuable help of Ana Sofia Almeida, Carla CCR de Carvalho, João Manuel Bernardo, Margarida Cristo and Vítor Encarnação. We thank João Reis for contributing with the detailed photographs of Triops spp. external morphology. We thank two anonymous reviewers for their helpful suggestions that improved the manuscript.

\section{REFERENCES}

ALBUFERA DE VALÊNCIA. 2009. Avifauna. Available at: http:/www.albufera.com/parque/book/ex port/html/6261 (Accessed 1.10.2016; in Spanish).

ALONSO, M. 1985. A survey of the Spanish euphyllopoda. Miscellània Zoològica, 9: 179-208.

ALONSO, M. 1996. Crustacea, Branchiopoda. In: Fauna Ibérica, vol. 7. (M. A. Ramos et al., Ed.). 
Museo Nacional de Ciencias Naturales, CSIC, Madrid. DOI:10.1163/193724097X00189

ASSOCIAÇÃO DE REGANTES E BENEFICIÁRIOS DO VALE DO SORRAIA. 2012. Agricultural map. Available at: http://www.arbvs.pt/carta agricola (Accessed 22.10.2016; in Portuguese).

BAKER, H.G. 1955. Self-compatibility and establishment after 'long-distance' dispersal. Evolution, 9: 347-349. DOI:10.2307/2405656

BIRDLIFE INTERNATIONAL. 2015. Species. Available at: http://www.birdlife.org/datazone/species (Accessed at 22.10.2016).

BOIX, D. 2002. Aportació al coneixement de la distribució d'anostracis i notostracis (Crustacea: Branchiopoda) als Països Catalans. Butlletí de la Institució Catalana d'Història Natural, 70: 55-71.

BOIX, D., J. SALA \& R. MORENO-AMICH. 2002. Population dynamics of Triops cancriformis (Crustacea: Branchiopoda: Notostraca) of the Espolla temporary pond in the northeastern Iberian peninsula. Hydrobiologia, 486: 175-183. DOI:10. 1023/A:1021350802144

CARVALHO, R.N. 1944. Catálogo da colecção de invertebrados de Portugal existentes no Museu Zoológico da Universidade de Coimbra. Crustacea. Memórias e Estudos do Museu Zoológico da Universidade de Coimbra, 160: 1-15.

ELPHICK, C. 2010. Why Study Birds in Rice Fields?. Waterbirds 33 (Special Publication 1): 1-7. DOI:10.1675/063.033.s101

ENGELMANN, M., T. HAHN \& G. HOHEISEL 1997. Ultrastructural characterization of the gonads of Triops cancriformis (Crustacea, Notostraca) from populations containing both females and males: no evidence for hermaphroditic reproduction. Zoomorphologie, 117: 175-180. DOI:10. 1007/s004350050042

FORÉS, E., M. MENÉNDEZ \& F.A. COMÍN. 1986. Contribución al conocimiento de crustáceos y rotíferos del Delta del Ebro. Miscellània Zoològica, 10: 105-111.

FRYER, G. 1988. Studies on the functional morphology and biology of the Notostraca (Crustacea: Branchiopoda). Philosophical Transactions of the Royal Society of London, Series B, 321: 27-124. DOI:10.1098/rstb.1988.0091

GAND, G., J. GARRIC \& J. LAPEYRIE. 1997. Biocénoses à triopsidés (Crustacea, Branchiopoda) du Permien du bassin de Lodève (France). Geobios, 30: 673-700. DOI:10.1016/S0016-6995(97)80157$\mathrm{X}$
GHIGI, A. 1921. Ricerche sui Notostraci di Cirenaica e di altri paesi del Mediterraneo. Atti della Società italiana di scienze naturali e del Museo civico di storia naturale di Milano, 60: 161-188.

GILL, R.E., T. PIERSMA, G. HUFFORD, R. SERVRANCKX \& A. RIEGEN. 2005. Crossing the ultimate ecological barrier: evidence for an 11000km-long nonstop flight from Alaska to New Zealand and eastern Australia by bar-tailed godwits. The Condor, 107:1-20. DOI:10.1650/7613

GLEMIN, S., E. BAZIN \& D. CHARLESWORTH. 2006. Impact of mating systems on patterns of sequence polymorphism in flowering plants. Proceedings of the Royal Society B Biological Sciences, 273: 3011-3019. DOI:10.1098/rspb.2006. 3657

GOLFIERI, B. \& L. BONATO. 2014. Recent distribution of Triops cancriformis in northern Italy (Crustacea: Notostraca). Bollettino del Museo Civico di Storia Naturale di Verona, 38: 127-131.

GREEN, A.J., \& J. FIGUEROLA. 2005. Recent advances in the study of long-distance dispersal of aquatic invertebrates via birds. Diversity and Distributions, 11: 149-156. DOI:10.1111/j.13669516.2005.00147.x

GUTHÖRL, P. 1934. Die Arthropoden aus dem Carbon und Perm des Saar-Nahe-Pfalz-Gebietes. Im Vertrieb bei der Preußischen Geologischen Landesanstalt, 44(4): 1-279.

HASSAN, M.M.S.M. 2015. The large branchiopod, Triops cancriformis simplex (Gihi, 1921) (Crustacea: Notostraca) in temporary rain pools, recorded for the first time in Taif-KSA. The Journal of Basic and Applied Zoology, 69: 1-9. DOI:10. 1016/j.jobaz.2015.04.006

KORN, M. \& A.K. HUNDSDOERFER. 2006. Evidence for cryptic species in the tadpole shrimp Triops granarius (Lucas, 1864) (Crustacea: Notostraca). Zootaxa, 1257: 57-68.

KORN, M., F. MARRONE, J.L. PÉREZ-BOTE, M. MACHADO, M. CRISTO, L. CANCELA DA FONSECA \& A.K. HUNDSDOERFER. 2006. Sister species within the Triops cancriformis lineage (Crustacea, Notostraca). Zoological Scripta, 35(4): 301-322. DOI:10.1111/j.1463-6409.2006. 00230.x

KORN, M, A.J. GREEN, M. MACHADO, J. GARCÍA-DE-LOMAS, M. CRISTO, L. CANCELA DA FONSECA, D.A. FRISCH, J.L. PÉREZ-BOTE \& A.K. HUNDSDOERFER. 2010. Phylogeny, molecular ecology and taxonomy of southern Ibe- 
rian lineages of Triops mauritanicus (Crustacea: Notostraca). Organisms Diversity and Evolution, 10(5): 409-440. DOI:10.1007/s13127-010-0026-y

KORN, M., N. RABET, H.V. GHATE, F. MARRONE, A.K. HUNDSDOERFER. 2013. Molecular phylogeny of the Notostraca. Molecular Phylogenetics and Evolution, 69(3): 1159-1171. DOI: 10.1016/j.ympev.2013.08.006

KORN, M. \& A.K. HUNDSDOERFER. 2016. Molecular phylogeny, morphology and taxonomy of Moroccan Triops granarius (Lucas, 1864) (Crustacea: Notostraca), with the description of two new species. Zootaxa, 4178(3): 328-346. DOI:10.1164 6/zootaxa.4178.3.2

LONGHURST, A.R. 1955. A review of the Notostraca. Bulletin of the British Museum (Natural History). Zoology, 3, 1-57. DOI:10.5962/bhl.part. 4119

LUSOSEM. 2010. Rice. Available at: http://www.luso sem.pt/arroz.html/A=14 (Accessed 22.10.2016; in Portuguese).

MACHADO, M. 2014. Amendment to the register of the specimen ${ }^{\circ} 212$ in Carvalho, R. N., 1944. Catálogo da colecção de invertebrados de Portugal existentes no Museu Zoológico da Universidade de Coimbra. Crustacea. Memórias e Estudos do Museu Zoológico da Universidade de Coimbra, 160: $1-15$.

MANTOVANI, B., M. CESARI, A. LUCHETTI \& F. SCANABISSI. 2008. Mitochondrial and nuclear DNA variability in the living fossil Triops cancriformis (Bosc, 1801) (Crustacea, Branchiopoda, Notostraca). Heredity, 100: 496-505. DOI:10.1038/ hdy.2008.3

MATHERS, T.C., R.L. HAMMOND, R.A. JENNER, T. ZIEROLD, B. HÄNFLING \& A. GÓMEZ. 2013 High lability of sexual system over 250 million years of evolution in morphologically conservative tadpole shrimps. BMC Evolutionary Biology, 13: 30. DOI:10.1186/1471-2148-13-30

McKENZIE, K.G. \& A. MORONI. 1986. Man as an agent of crustacean passive dispersal via useful plants - exemplified by Ostracoda ospiti esteri of the Italian ricefields ecosystem - and implications arising therefrom. Journal of Crustacean Biology, 6(2): 181-198. DOI:10.2307/1547979

MEUSEL, F. \& M. SCHWENTNER. 2016. Molecular and morphological delimitation of Australian Triops species (Crustacea: Branchiopoda: Notostraca) - large diversity and little morphological differentiation. Organisms, Diversity \& Evolution,
DOI:10.1007/s13127-016-0306-2. DOI:10.1007/ s13127-016-0306-2.

NOURISSON, M. \& A. THIERY. 1988. Introduction à la systématique des organismes des eaux continentales françaises. 9. Crustacés Branchiopodes (Anostracés, Notostracés, Conchostracés). Bulletin mensuel de la Société Linnéenne de Lyon, 57: 75-95 and 104-135. DOI:10.3406/linly.1988.10826

PANNELL, J.R. 2002. The evolution and maintenance of androdioecy. Annual Révue of Ecology and Systematics, 33: 397-425. DOI:10.1146/annu rev.ecolsys.33.010802.150419

PONT, D. \& A. VAQUER. 1986. Influence du phyllopode Triops cancriformis (Bosc.) sur la biocénose des rizières de Camargue. Acta Oecologica, 7: 7588.

SAHUQUILLO, M. 2012. Distribution and diversity of crustacean communities in Mediterranean ponds (Eastern Spain): relationship with climatic and limnological factors. Ph.D. Thesis. University of Valencia, Spain.

SASSAMAN, C. 1991. Sex ratio variation in femalebiased populations of Notostracans. Hydrobiologia, 212: 169-179. DOI:10.1007/978-94-011-336 6-1_19

SCANABISSI, F., E. EDER \& M. CESARI. 2005. Male occurrence in Austrian populations of Triops cancriformis (Branchiopoda, Notostraca) and ultrastructural observations of the male gonad. Invertebrate Biology, 124: 57-65. DOI:10.1111/j.17447410.2005.1241-07.x

THIÉRY, A. 1996. Large Branchiopods (Crustacea: Anostraca, Notostraca, Spinicaudata, Laevicaudata) from temporary inland waters of the Arabian Peninsula. Fauna of Saudi Arabia, 15: 37-98.

TOURENQ, C., R.E. BENNETTS, H. KOWALSKI, E. VIALET, J.-L. LUCCHESI, Y. KAYSER \& P. ISENMANN. 2001. Are ricefields a good alternative to natural marshes for waterbird communities in the Camargue, southern France? Biological Conservation, 100(3): 335-343. DOI:10.1016/S00063207(01)00037-4

TOURENQ, C., N. SADOUL, N. BECKA, F. MESLÉARD \& J.-L. MARTIN. 2003. Effects of cropping practices on the use of rice fields by waterbirds in the Camargue, France. Agriculture, Ecosystems and Environment, 95: 543-549. DOI:10. 1016/S0167-8809(02)00203-7

TRENTINI, M. \& F. SCANABISSI. 1979 Ultrastructural observations on the oogenesis of Triops can- 
criformis (Crustacea, Notostraca). Cell and Tissue Research, 194: 71-77. DOI:10.1007/BF00209234

TRUSHEIM, F. 1938. Triopsiden (Crust. Phyll.) aus dem Keuper Frankens. Palaeontologische Zeitschrift, 19: 198-216.

VANSCHOENWINKEL, B., T. PINCEEL, M.P.M. VANHOVE, C. DENIS, M. JOCQUE, B.V. TIMMS, B.V., BRENDONCK L. 2012. Toward a Global Phylogeny of the "Living Fossil" Crustacean Order of the Notostraca. PLOS ONE 7: e34998. DOI:10.1371/journal.pone.0034998

VASCONCELOS, T., M. TAVARES \& N. GASPAR. 1999. Aquatic plants in the rice fields of the Tagus Valley, Portugal. Hydrobiologia, 415: 5965. DOI: $10.1023 / \mathrm{A}: 1003873315570$

VIANA, D.S., L. SANTAMARÍA \& J. FIGUEROLA. 2016. Migratory Birds as Global Dispersal Vectors. Trends in Ecology \& Evolution, 31(10): 763 775. DOI:10.1016/j.tree.2016.07.005

WEEKS, S.C., T.F. SANDERSON, S.K. REED, M. ZOFKOVA, B. KNOTT, U. BALARAMAN, G. PEREIRA, D.M. SENYO \& W.R. HOEH.
2006. Ancient androdioecy in the freshwater crustacean Eulimnadia. Proceedings of the Royal Society B: Biological Sciences, 273: 725-734. DOI: 10.1098/rspb.2005.3370

WIKIPEDIA. 2016. Lavanco. Available at https://gl. wikipedia.org/wiki/Lavanco (Accessed 1.10.2016).

ZAFFAGNINI, F. \& M. TRENTINI. 1980. The distribution and reproduction of Triops cancriformis (Bosc) in Europe (Crustacea Notostraca). Monitore Zoologico Italiano (N S), 14: 1-8. DOI:10.10 80/00269786.1980.10736342

ZIEROLD, T., B. HANFLING, \& A. GÓMEZ. 2007. Recent evolution of alternative reproductive modes in the 'living fossil' Triops cancriformis. BMC Evolutionary Biology, 7: 161. DOI:10.1186/14712148-7-161

ZIEROLD, T., J. MONTERO-PAU, B. HÄNFLING \& A. GÓMEZ. 2009. Sex ratio, reproductive mode and genetic diversity in Triops cancriformis. Freshwater Biology, 54: 1392-1405. DOI:10.1111/ j.1365-2427.2009.02191.x

Con la colaboración de:

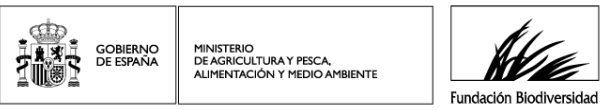

